\title{
A mikro-RNS-ek patogenetikai szerepe és expressziós mintázata praeeclampsiában
}

\author{
Biró Orsolya - Rigó János Jr. dr. \\ Semmelweis Egyetem, Általános Orvostudományi Kar, I. Szülészeti és Nőgyógyászati Klinika, Budapest
}

\begin{abstract}
A praeeclampsia súlyos anyai és magzati szövődményekkel járó kórkép, mely a terhességek 3-8\%-át érinti világszerte. Legfőbb tünetei a 20. terhességi hét után jelentkező magas vérnyomás és a kóros fehérjevizelés. A betegség kialakulásának oka a mai napig vitatott. A mikro-RNS-ek rövid, nem kódoló RNS-molekulák, amelyek fontos szerepet töltenek be az eukaryota gének poszttranszkripciós szabályozásában. Olyan alapvető élettani folyamatok finomhangolásában vesznek részt, mint a sejtciklus, a proliferáció, a differenciáció és a sejthalál. Genomszintű vizsgálatok során a placentában több száz mikro-RNS-t azonosítottak, melyek feltehetően részt vesznek a placentáció szabályozásában, és szükségesek a terhesség zavartalan lefolyásához. Több tanulmány számolt be a mikro-RNS-ek megváltozott expressziójáról terhességi kórképekben. A rendellenes mikro-RNS-szabályozás hozzájárulhat a praeeclampsia kialakulásához, mivel befolyásolja a trophoblastsejtek proliferációját, migrációját és invázióját, a spirális artériák remodellingjét és az angiogenezist. A placentáris mikro-RNS-ek egy része (például a C19MC mikro-RNS-klaszter tagjai) a trophoblastsejtek által termelt exoszómák révén kijut az anyai véráramba. Ezek az úgynevezett „keringő” mikro-RNS-ek stabilitásuk és specifikusságuk révén biomarkerként szolgálhatnak különböző placentaeredetű kórképek kimutatására. Orv Hetil. 2018; 159(14): 547-556.
\end{abstract}

Kulcsszavak: praeeclampsia, mikro-RNS, placenta, vérplazma

\section{The pathogenetic role and expression profile of microRNAs in preeclampsia}

Preeclampsia is the leading cause of maternal and fetal morbidity and mortality that affects $3-8 \%$ of pregnancies worldwide. Its main symptoms include new onset of high blood pressure and proteinuria after 20 weeks of pregnancy. The cause of the disease is still debated. microRNAs are short, non-coding RNA molecules that play a pivotal part in the posttranscriptional regulation of eukaryotic genes. They are involved in fine-tuning of vital physiological processes such as cell cycle, proliferation, differentiation and cell death. In genomic studies, hundreds of microRNAs were detected in the placenta, which are supposed to regulate placental development and contribute to uncomplicated pregnancy. Several studies have reported changes in the expression of microRNAs in pregnancy. Abnormal microRNA expression may have a role in the development of preeclampsia as it affects the proliferation, migration, and invasion of the trophoblast cells, spiral artery remodeling, and angiogenesis. Some placental microRNAs (e.g., the C19MC microRNA cluster) are able to reach the maternal circulation through their release via exosomes from the trophoblast layer. These 'circulating' microRNA molecules can be applied as biomarkers for the detection of various placental disorders owing to their stability and specificity.

Keywords: preeclampsia, microRNA, placenta, blood plasma

Biró O, Rigó J Jr. [The pathogenetic role and expression profile of microRNAs in preeclampsia]. Orv Hetil. 2018; 159(14): 547-556.

(Beérkezett: 2017. december 12.; elfogadva: 2018. január 11.) 


\section{Rövidítések}

CTB = cytotrophoblast; DGCR8 = DiGeorge syndrome critical region-8; EDTA = etilén-diamin-tetraecetsav; EFNA3 = ephrin-A3; EVT = extravillosus trophoblast; HOXA9 = homeobox-A9; HRE = hypoxiareszponzív elem; HSD17Bl = 17 $\beta$-hidroxiszteroid-dehidrogenáz- 1 ; HUVEC $=$ (human umbilical vein endothelial cells) humán köldökvénaendothelsejttenyészet; ISCU = iron-sulfur cluster assembly enzyme; IUGR $=($ intrauterin growth restriction $)$ intrauterin növekedési retardáció; $\mathrm{IVF}$ = in vitro fertilizáció; $\mathrm{KCMFI}=$ potassium channel modulatory factor- 1 ; miRISC $=($ miRNA-induced silencing complex) miRNS indukálta csendesítő komplex; miRNS = mikro-RNS; PLAP = placenta-alkalikusfoszfatáz; pre-miRNS = prekurzor miRNS; pri-miRNS = primer miRNS; SGHPL4 = Saint Georges Hospital placental cell line-4; SOLiD = Sequencing by Oligonucleotide Ligation and Detection; STB = syncytiotrophoblast; TLDA = TaqMan Low Density Array; TRBP = TAR RNA binding protein; TSG101 = tumor susceptibility gene $101 ;$ UTR $=$ nem transzlálódó régió; $\mathrm{VT}=$ villosus trophoblast

A praeeclampsia súlyos anyai és magzati szövődményekkel járó kórkép, mely a terhességek 3-8\%-át érinti világszerte [1]. A betegséget a terhesség 20 . hete után jelentkező magas vérnyomás és proteinurea definiálja. Fehérjevizelés hiányában a diagnózis egyéb anyai szervi zavarok, mint például thrombocytopenia, a májfunkciók károsodása, veseelégtelenség, tüdőödéma és korábban nem tapasztalt agyi vagy látási zavarok megléte alapján állítható fel [2].

A betegség kialakulásának oka a mai napig vitatott, az általánosan elfogadott elmélet szerint a klinikai tünetegyüttes a placenta perfúziós zavarának következménye $[3,4]$. Klinikai megjelenéstől függően korai és késői kezdetú formákat különíthetünk el [5]. A korai praeeclampsia esetében a tünetek a terhesség 34 . hete előtt jelentkeznek, melyeket az elégtelen trophoblastinvázió és spirális artéria remodelling vált ki [6]. Az esetek számottevő része társul intrauterin növekedési retardációval (IUGR), illetve gyakran végződik koraszüléssel [6]. A késői kezdetứ, kevésbé súlyos forma a 34. terhességi hét után jelentkezik, és vélhetôn az anyai cardiovascularis maladaptáció következménye [6]. Mindkét típus fokozott rizikót jelent a későbbi szív- és érrendszeri betegségek kialakulására az anya számára [7].

A placenta perfúziós zavarának következtében fokozódik a trophoblasttörmelék kibocsátása az anyai keringésbe. A trophoblastrétegből ily módon különböző káros anyagok, antiangiogén faktorok, proinflammatorikus mediátorok és extracellularis vesiculák szabadulnak fel $[8,9]$. Az anyában ennek hatására több szervrendszert érintő elváltozások alakulnak ki, melyeket endotheldiszfunkció, szisztémás gyulladás és az immunrendszer egyensúlyának felborulása jellemez [3].

\section{Extracellularis vesiculák}

Az extracellularis vesiculák sejteredetű kettôs foszfolipidmembránnal határolt struktúrák. Különböző tulajdonságaik alapján (méret, keletkezési mód és fehérjetartalom) több alcsoportba oszthatók: exoszómák, microvesiculák és apoptotikus testek. A vesiculák sejtbiológiai és élettani funkciói igen sokrétúek, termelődésük majdnem minden sejttípusban megfigyelhető [10]. Mindemellett számos betegségben potenciális diagnosztikai, prognosztikai és terápiás szereppel is bírnak. A kettős foszfolipidréteggel határolt exoszómák a legkisebb mérettartományú vesiculák (40-120 nm). Endoszomális eredetúek, a multivesicularis testek konstitutív vagy indukált exocytosisával ürülnek a sejten kívüli térbe [11]. Tartalmuk a forrás sejttípusoktól függően elég változatos, megtalálhatók bennük többek között kódoló és nem kódoló RNS-ek, illetve különböző típusú fehérjemolekulák. A sejtekből való szekréciót követôen modulálhatják a szomszédos sejtek aktivitását, vagy a szervezeten belül távoli pontokra jutva, nem hormonális módon képesek intercellularis kommunikációra [12]. A különféle sejttípusokból származó exoszómák fehérjéinek összetétele nagy részben megegyezik, univerzális endoszomális fehérjemarkerek (például CD63, CD81 és TSG101) kimutatásával azonosíthatók [13]. A placentából felszabaduló exoszómák specifikus, placenta-alkalikusfoszfatáz (PLAP) marker protein alkalmazásával különíthetők el [14]. Élettani terhesség esetén a trophoblasteredetű exoszómák a 6 . gesztációs héttől mutathatók ki az anyai keringésben [14]. Számuk a terhesség folyamán fokozatosan növekszik, és a szülés után 48 órán belül eliminálódnak a vérkeringésbőll [14].

A placenta által kibocsátott exoszómák szintje és azok tartalma információt nyújt a terhesség lefolyásáról, ezáltal biomarkerként szolgálhatnak különböző kórképek kimutatására. Praeeclampsiában a placentadiszfunkció a trophoblasteredetǔ vesiculák fokozott szekrécióját okozza, ami által megnövekszik az exoszomális faktorok, köztük a mikro-RNS-ek (miRNS) szintje is az anyai keringésben (1. ábra) [9]. Több tanulmány számolt be a miRNS-ek megváltozott expressziójáról praeeclampsiában [15-18] és egyéb terhességi kórképekben $[19,20]$.

\section{miRNS-ek}

\section{Biogenezis és funkció}

A miRNS-ek rövid (15-23 nukleotid), egyszálú nem kódoló RNS-molekulák, melyek fontos szerepet játszanak az eukaryota gének poszttranszkripciós szabályozásában [21]. A miRBase adatbázisban 1881 humán miRNS-prekurzor és 2588 érett miRNS található [22]. A miRNS-eket kódoló gének a genom intra- és intergenikus régióiban találhatók; a legtöbb esetben a fehérjét kódoló gének intronikus szakaszain lokalizálódnak, ame- 


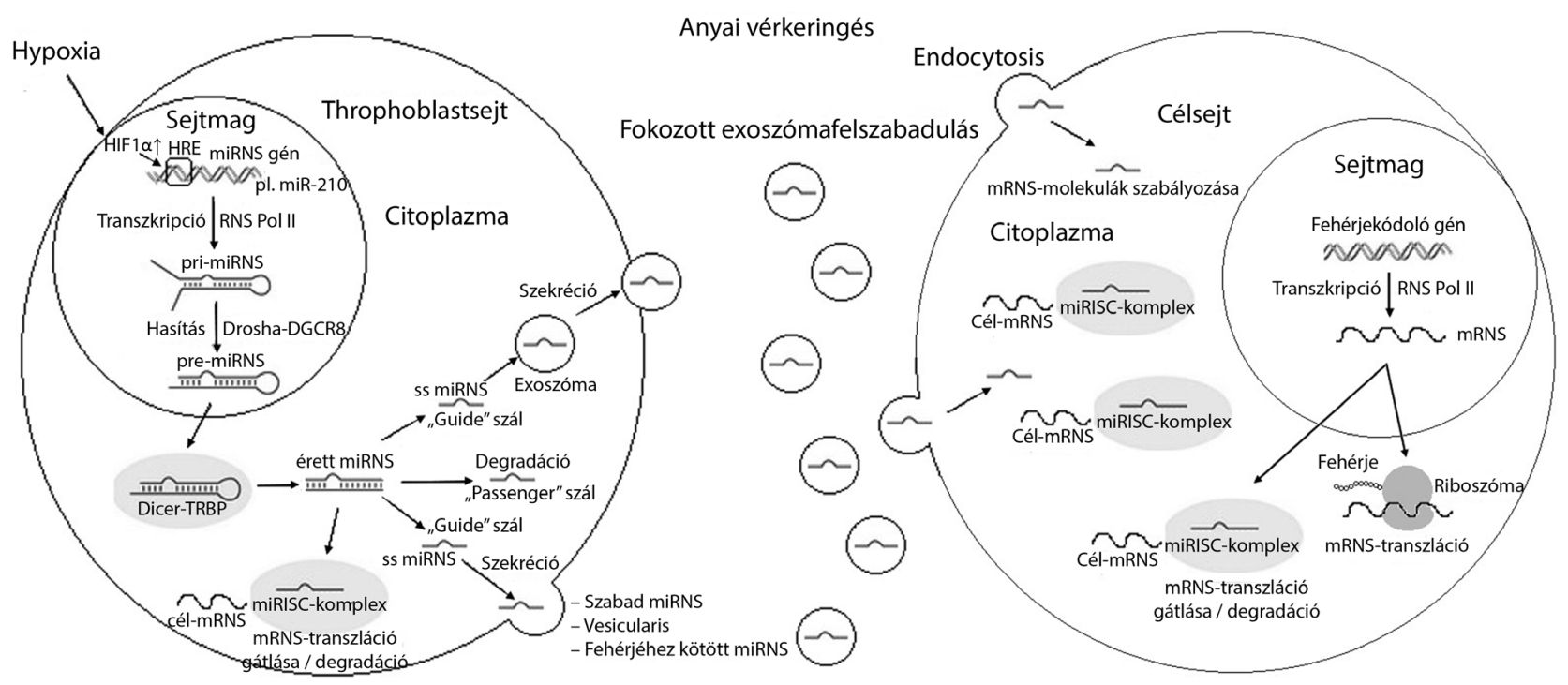

l. ábra | miRNS-biogenezis, exoszomális szekréció és hatásmechanizmus praeeclampsiában a hsa-miR-210 példáján keresztül

lyek a transzkripció során kivágódnak az mRNS előalakból. A miRNS-eket kódoló gének kisebb része önálló transzkripciós egységként múködik, ezek a genom nem kódoló, intergenikus régióiban találhatók [23].

A miRNS-ek prekurzor alakja az mRNS-ektől eltérően kettős szálú, s többlépéses érési folyamat során válnak egyszálúvá. Transzkripciójában a II-es típusú RNS-polimeráz vesz részt, amely először úgynevezett „hajtüprekurzort" hoz létre, a primer miRNS-t (pri-miRNS). A pri-miRNS-t, amely kódolhat egyetlen miRNS-t vagy akár egy miRNS-klasztert, még a sejtmagon belül a Drosha-DGCR8 komplex hasítja el. A keletkező intermedier terméket pre-miRNS-nek nevezzük. Ezután a sejtmagból a citoplazmába jutva a Dicer-TRBP komplex eltávolítja róla a terminális hurkot, 20-24 nukleotid hosszúságú kettôs szálat eredményezve. A duplex ezután egy Argonauta (Ago)-fehérjével kapcsolódik, majd a cél-mRNS-sel komplementer szál („guide strand”) kiválasztódásával létrejön az effektorfunkciót ellátó miRISC (miRNS indukálta csendesítő komplex) ribonukleoproteinkomplex. A másik szál („passenger strand”) a folyamat során kiválik a komplexből, és degradálódik [23].

A miRNS-ek hatásukat negatív reguláció révén fejtik ki: az mRNS-szekvenciák nem transzlálódó végéhez (3'UTR) kötődve gátolják annak transzlációját, vagy teljes komplementaritás esetén degradálódást idéznek elő. A miRNS 5' vége tartalmazza az mRNS-szekvenciával komplementer, 7 nukleotid hosszúságú úgynevezett „seed” régiót. Egy mRNS számos miRNS-kötő helyet tartalmazhat, és egy miRNS több mRNS-célponttal is rendelkezhet, ami a génexpresszió finomhangolását teszi lehetôvé $[24,25]$. A miRNS-ek komplex szabályozási hálózatok részei, expressziós mintázatukra tér- és időbeli specificitás jellemző́. Ugyanaz a miRNS különböző szövetekben eltérő módon fejeződhet ki, más mRNS- célpontokkal rendelkezhet, és ezáltal sokféle funkciót láthatnak el. Olyan alapvető élettani folyamatok irányításában vesznek részt, mint a sejtciklus, a proliferáció, a differenciáció és a sejthalál [25].

\section{Placentában expresszálódó miRNS-ek, szerepük praeeclampsiában}

Genomszintû vizsgálatok során a placentában több száz miRNS-t azonosítattak [26], melyek egy része kizárólag a placentában, nagyobb hányaduk más szövetekben is kifejeződik. A terhesség folyamán betöltött funkciójuk a mai napig nem tisztázott, feltehetően részt vesznek a placentáció szabályozásában, és szükségesek a terhesség zavartalan lefolyásához [27].

A miRNS-biogenezis kanonikus útvonalában szereplő valamennyi kulcsmolekula szintén megtalálható a placentában [28]. Az Ago2-fehérjéről bebizonyították, hogy elengedhetetlen az egérembriogenezis korai stádiumaihoz [29], s mutációja a placenta fejlődési zavarához és embrionális halálozáshoz vezet [30]. A placentában expresszálódó miRNS-ek az evolúció késői szakaszában jelentek meg, és kizárólag az emlős fajokra jellemzőek [31]. A legnagyobb számban a villosustrophoblast (VT)rétegben vannak jelen, és a terhesség különböző szakaszaiban eltérő módon fejeződnek ki [16, 32]. A miRNSek szerepet játszanak a placenta génjeinek dinamikus szabályozásában, élettani koncentrációjuk különböző szignáltranszdukciós kaszkádok, illetve környezeti faktorok (hypoxia, oxidatív stressz stb.) révén megváltozhat.

Léteznek úgynevezett placentaspecifikus miRNS-ek, melyek egyéb szövetekben élettani körülmények között nem expresszálódnak: a 14-es és 19-es kromoszómán elhelyezkedő miRNS-klaszterek (C14MC és C19MC), 


\section{$19 q 13.41$}

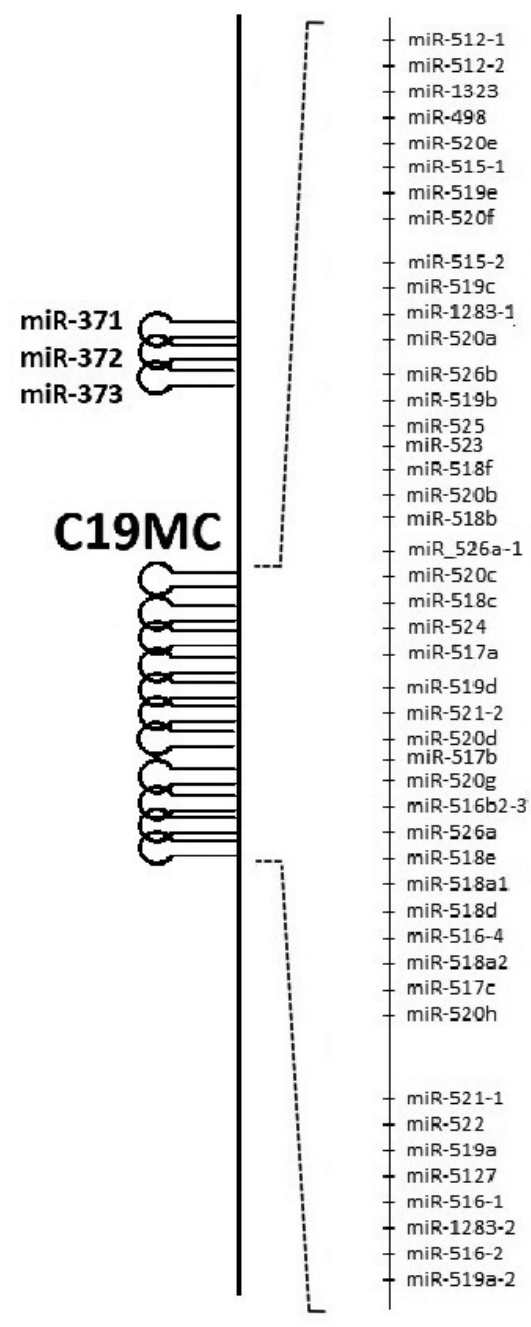

2. ábra

illetve a miR-371-373-család. A C14MC 34 érett miRNS-et foglal magában, a méhlepényes emlősök között evolúciósan konzervált [33]. A C19MC 46 különböző miRNS-hajtúszerkezetet tartalmaz, melyekről 59 érett miRNS képződik, s ezáltal a legnagyobb ismert miRNS-klaszter; kizárólag főemlősökben található meg (2. ábra) [34]. Mindkét klaszter genetikailag imprintált, ám a terhesség folyamán eltérő expressziós tendenciát mutatnak. A C14MC miRNS-ek az anyai allélról fejeződnek ki, szintjük az első trimeszterben a legmagasabb, majd a terhesség előrehaladtával fokozatosan csökken [32]. Ezzel szemben a C19MC miRNS-ek esetében az apai allél aktív [35], és expressziójuk korai aktivációt követően a gesztációs korral fokozódik [32]. Élettani terhességben a növekvő tendencia az anyai vérkeringésben is mérhető $[36,37]$. A miR-371-373-család szintén a 19-es kromoszómán helyezkedik el, terhességben betöltött funkciójáról azonban keveset tudunk [38]. A jelen kutatások középpontjában a C19MC áll, mivel a placentában expresszálódó miRNS-ek nagy százalékát e klaszter tagjai teszik ki. Bebizonyosodott, hogy ezek a
miRNS-ek elengedhetetlen funkciókat látnak el a terhesség folyamán, és kóros kifejeződésük feltehetően patogenetikai tényezőként jelölhető meg különböző terhességi kórképekben.

A miRNS-ek rendellenes expressziója hozzájárulhat a praeeclampsia kialakulásához, mivel befolyásolják a trophoblastsejtek invázióját, a spirális artériák remodellingjét és az angiogenezist, illetve immunológiai szereppel is bírnak. Az 1. táblázatban a betegséggel mind ez idáig összefüggésbe hozott, ismert funkciójú és célpontú miRNS-ek listája látható [39-59]. A proangiogén/antiangiogén faktorok egyensúlyának megbomlása jól ismert jelenség praeeclampsiában. Placentában és trophoblastsejtvonalakban számos, az angiogenezist befolyásolni képes miRNS-t (úgynevezett angiomiR-t) leírtak, úgymint a betegségben jelentősen megemelkedett miR-155 és $m i R-210[41,43,44]$. Sok miRNS-ről, köztük a $m i R$ 17-92-család tagjairól bebizonyosodott, hogy szabályozzák a trophoblastsejtek proliferációját, migrációját [53]. Élettani terhességben az immunológiai folyamatok irányítását számos kis szabályozó RNS-molekula végzi. Többek között a $m i R-494$, a $m i R-181$ a és a $m i R-152$ különböző immunsejtek funkcióját szabályozza, melyek felborulása a praeeclampsiára jellemző gyulladásos reakciók kialakulásához vezethet [55-57].

A betegség hátterében álló komplex folyamatok feltérképezéséhez rendszerbiológiai megközelítés szükséges. Bioinformatikai eszközök segítségével miRNS-szabályozási hálózatok hozhatók létre. Saját vizsgálatunkban olyan kulcsfontosságú miRNS-mRNS interakciók feltérképezését tüztük ki célul, amelyek kapcsolódhatnak a betegség patomechanizmusához [60]. Nyilvánosan elérhető, lepényi miRNS- és génexpressziós profilok integrációjával miRNS-szabályozási hálózatot építettünk, és meghatároztuk a betegmintákban eltérő mintázatokat. Az azonosított miRNS-mRNS kölcsönhatásokból a $h s a-$ mir-210 volt a hálózat legnagyobb fokszámú csomópontja, mely miRNS-nek a betegségben betöltött szerepe jól ismert.

A C19MC miRNS-ek extravillosus trophoblast (EVT-) eredetű sejtvonalban történő expresszáltatása (élettani körülmények között itt nem fejeződnek ki) a sejtek migrációs képességét csökkenti a proliferáció vagy apoptózis befolyásolása nélkül. Microarraytechnikával megerősítették, hogy a C19MC-klaszter tagjai a sejtek mozgásával kapcsolatos transzkriptumokat szabályozzák [61].

A $m i R-517$-család tagjai $(m i R-517 a, m i R-517 b, m i R-$ $517 c$ ) praeeclampsia esetén a placentában magasabb koncentrációban találhatók meg, továbbá azt is bebizonyították, hogy hypoxia hatására indukálódnak, és gátolják a trophoblastinváziót. Megemelkedett szintjük in vitro sejtmodellben a betegségben kulcsfontosságú szerepet játszó, antiangiogén sFltl-fehérje fokozott termelődéséhez vezet [62]. Kimutatták, hogy a C19MC miRNS-eknek a virális fertőzések elleni védekezésben is szerepük van. A klaszter tagjai trophoblasteredetű exoszómákba 
1. táblázat | Praeeclampsia kialakulásával és kórlefolyásával összefüggésbe hozott, placentában expresszálódó miRNS-ek. : emelkedés, $\downarrow$ : csökkenés

\begin{tabular}{|c|c|c|c|c|}
\hline Szabályozott funkció & miRNS-ek & Expresszió & Validált célpontok és útvonalak & Irodalom \\
\hline \multirow[t]{6}{*}{ Angiogenezis } & $m i R-16, m i R-29 b$ & $\uparrow$ & VEGF-A, CCNE1 & [39] \\
\hline & $m i R-494$ & $\uparrow$ & CDK6/CYCDl & {$[40]$} \\
\hline & $\begin{array}{l}m i R-17, m i R-20 a \\
m i R-20 b\end{array}$ & $\uparrow$ & Ephrin-B2, -B4 & [39] \\
\hline & $m i R-155$ & $\uparrow$ & CYR61 $(\rightarrow$ VEGF $\downarrow)$ & {$[41]$} \\
\hline & $m i R-21$ & $\downarrow$ & AKT és ERKl / 2 útvonalak & {$[42]$} \\
\hline & $m i R-210$ & $\uparrow$ & EFNA3, HOXA9, HSD17B1 & {$[43,44]$} \\
\hline \multirow[t]{6}{*}{ Trophoblastinvázió } & $m i R-125 b-1-3 p$ & $\uparrow$ & SIPR & {$[45]$} \\
\hline & $m i R-34 a$ & $\downarrow$ & SERPINA3 & {$[46]$} \\
\hline & $m i R-210$ & $\uparrow$ & KCMF1 & {$[47]$} \\
\hline & $m i R-155$ & $\uparrow \uparrow$ & CYCDI, eNOS & {$[48,49]$} \\
\hline & $\begin{array}{l}m i R-378 a-5 p, m i R-376 c \\
m i R-21\end{array}$ & $\downarrow$ & ALK7, Nodal útvonal & {$[50-52]$} \\
\hline & miR-17-92-klaszter & $\uparrow$ & hGCMl, hCYP19Al & {$[53]$} \\
\hline \multirow{6}{*}{$\begin{array}{l}\text { Gyulladásos } \\
\text { folyamatok }\end{array}$} & $m i R-155$ & $\uparrow$ & IRAKM, NKIRASl, PTEN $\left(\rightarrow \mathrm{APl} / \mathrm{NF}_{\kappa} \mathrm{B} \uparrow\right)$ & {$[54]$} \\
\hline & $m i R-494$ & $\uparrow$ & PGE2 & {$[55]$} \\
\hline & $m i R-181 a$ & $\uparrow$ & TGFß-útvonal (TGFBRl, TGFBRAPl) & {$[56]$} \\
\hline & $m i R-152$ & $\uparrow$ & HLA-G & {$[57]$} \\
\hline & $m i R-210$ & $\uparrow$ & STAT6/IL4 útvonal & {$[58]$} \\
\hline & $m i R-125 b-1-3 p$ & $\uparrow$ & SGPLl $(\rightarrow \operatorname{IL8} \uparrow)$ & [59] \\
\hline
\end{tabular}

csomagolódnak, és a recipiens sejtekben autofágia indukálásával gátolják a vírusreplikációt $[63,64]$.

Összefoglalva elmondható, hogy a trophoblastsejtek szerteágazó funkciót látnak el, és hatásukat vesiculák révén közvetítik a placenta más részei, illetve az anyai sejtek felé. A placentában expresszálódó miRNS-ek jelentős része a syncytiotrophoblast (STB)-rétegből aktív vagy passzív szekréció révén kijut az anyai véráramba [9].

\section{Keringö miRNS-ek a terhesség során, jelentôségük biomarkerként}

A keringő miRNS-ek extracellularis vesiculákba csomagolódva, lipoproteinhez vagy fehérjéhez (Ago) kötötten fordulnak elő, aminek köszönhetően a közegre jellemző nagyfokú RNáz-aktivitással szemben védettséget élveznek. Stabilitásukat megőrzik olyan szélsőséges körülmények között is, mint a többszöri fagyasztási-olvasztási ciklusok, a magas, illetve alacsony $\mathrm{pH}$ és a hosszú tárolási idő $[65,66]$. Ezen tulajdonságaikat kihasználva, a keringő miRNS-ek potenciális biomarkerként szolgálhatnak különböző kórképek diagnosztikájában, prognosztikájában és a terápiás hatás vizsgálatában.

A terhességgel összefüggésben lévő, de nem kizárólag placentaeredetû́ miRNS-ek az anyai vérben detektálhatók: mennyiségük a terhesség előrehaladtával megnő, majd a szülés után visszaáll a nem terhes egyénekben mért szintre. A placentaspecifikus miRNS-ek a nem ter- hes egyének vérében nem mutathatók ki, az anyai keringésben mérhetők; mennyiségük a terhesség elörehaladtával megnő, szülés után pedig eliminálódnak a vérkeringésből. A praeeclampsiában eltérő expressziót mutató keringő miRNS-ek a 2. táblázatban kerültek összefoglalásra [36, 44, 67-77].

A placentaspecifikus mikro-RNS-ek keringésben mért koncentrációja korai lepényleválás esetén megváltozik. Egy vizsgálat során a $C 19 M C$-klaszter bizonyos tagjainak (miR-515-3p, -517a, -517c és -518b) plazmakoncentrációit mérték a 25 . és a 40 . terhességi hét között. Bebizonyították, hogy a keringő $m i R-517 c$ szintje az anyai plazmában megnövekedett a lepényleválás következtében, aminek oka feltehetôen a trophoblasttörmelékek fokozott felszabadulása [78]. In vitro fertilizációs (IVF-) programban részt vevő terhesek keringésében már 2 héttel az implantáció után detektálhatók voltak C19MC miRNS-ek [37]. Szintjük a terhesség előrehaladtával mind a plazmában, mind izolált exoszómafrakcióban fokozatosan emelkedett. A klaszter korai megjelenése arra utal, hogy tagjai szerepet játszhatnak az anyai-magzati felszín kialakításában [37]. Humanizált egérmodellben lehetőség nyílt a placentaspecifikus miRNS-ek anyai és magzati keringésben történő vizsgálatára. Az egerekben természetes körülmények között nem expresszálódik a C19MC-klaszter, azonban transzgenikus állatot létrehozva a humán szervezetnek megfelelő miRNS-mintázat figyelhető meg [79]. Nem terhes állatokban különböző szövetekben gyenge, míg terhe- 
2. táblázat |Anyai keringésben eltérő expressziót mutató miRNS-ek praeeclampsiában. $\uparrow:$ emelkedés, $\downarrow$ : csökkenés

\begin{tabular}{|c|c|c|c|c|c|}
\hline Gesztációs kor & Mintatípus & Módszer & Szint & miRNS-ek & Irodalom \\
\hline \multirow[t]{2}{*}{ 1. trimeszter } & \multirow[t]{2}{*}{ Szérum } & \multirow[t]{2}{*}{ TLDA, RT-PCR-validálás } & $\uparrow$ & $m i R-1233$, miR-520a, miR-210 & \multirow[t]{2}{*}[67]{} \\
\hline & & & $\downarrow$ & $m i R-144$ & \\
\hline 1-2. trimeszter & EDTA-plazma & RT-PCR & $\uparrow$ & $\begin{array}{l}m i R-516-5 p, m i R-517^{*}, m i R-518 b, m i R-520 a^{*} \\
m i R-520 h, m i R-525, m i R-526 a\end{array}$ & {$[36,68]$} \\
\hline 2-3. trimeszter & Szérum & RT-PCR & $\uparrow$ & $m i R-210$ & [69] \\
\hline \multirow[t]{2}{*}{ 2-3. trimeszter } & \multirow[t]{2}{*}{ Plazma } & \multirow[t]{2}{*}{ RT-PCR } & $\uparrow$ & $m i R-210$ & \multirow[t]{2}{*}[70]{} \\
\hline & & & $\downarrow$ & $m i R-18 a, m i R-19 b 1$, miR-92a-1 & \\
\hline \multirow[t]{2}{*}{ 3. trimeszter } & \multirow[t]{2}{*}{ Szérum } & \multirow[t]{2}{*}{$\begin{array}{l}\text { Új generációs szekvenálás } \\
\text { (NGS) }\end{array}$} & $\uparrow$ & $\begin{array}{l}\text { miR-521, miR-520h, miR-517c, miR-519d, } \\
m i R-520 g, \text { miR-517b, miR-542-3p, miR-136, } \\
\text { let7-f1*, miR-518e, let-7a*, miR-125b, miR-125a- } \\
5 p, m i R-519 a, m i R-29 a\end{array}$ & \multirow[t]{2}{*}[71]{} \\
\hline & & & $\downarrow$ & $\begin{array}{l}\text { let-7f, miR-223, miR-1260, let7d, miR-320c, } \\
m i R-185, \text { miR-1272 }\end{array}$ & \\
\hline 3. trimeszter & EDTA-plazma & RT-PCR & $\uparrow$ & $\begin{array}{l}\operatorname{miR}-516-5 p, m i R-517^{*}, m i R-520 a^{*}, m i R-525 \\
m i R-526 a\end{array}$ & {$[72]$} \\
\hline \multirow[t]{2}{*}{ 3. trimeszter } & \multirow[t]{2}{*}{ EDTA-plazma } & \multirow[t]{2}{*}{ RT-PCR } & $\uparrow$ & $m i R-210$ & \multirow[t]{2}{*}[73]{} \\
\hline & & & $\downarrow$ & $m i R-152$ & \\
\hline 3. trimeszter & EDTA-plazma & $\begin{array}{l}\text { Microarray, RT-PCR-vali- } \\
\text { dálás }\end{array}$ & $\uparrow$ & $\begin{array}{l}m i R-574-5 p, \text { miR-26a, miR-181a, miR-130b, } \\
m i R-103, \text { miR-342-3p, miR-24 }\end{array}$ & {$[74]$} \\
\hline 3. trimeszter & EDTA-plazma & RT-PCR & $\uparrow$ & $m i R-210$ & {$[44]$} \\
\hline \multirow[t]{2}{*}{ 3. trimeszter } & \multirow[t]{2}{*}{ EDTA-plazma } & \multirow[t]{2}{*}{$\begin{array}{l}\text { SOLiD-szekvenálás, } \\
\text { RT-PCR-validálás }\end{array}$} & $\uparrow$ & miR-14l és miR-29a & \multirow[t]{2}{*}[75]{} \\
\hline & & & $\downarrow$ & $m i R-144$ & \\
\hline 3. trimeszter & Plazma & RT-PCR & $\uparrow$ & $\begin{array}{l}\operatorname{miR}-181 a-5 p, \text { miR-195-5p, miR-155-5p, } \\
\text { miR-17-5p, miR-126-3p, miR-221-3p }\end{array}$ & [76] \\
\hline 3. trimeszter & Exoszóma & RT-PCR & $\uparrow$ & $m i R-210$ & {$[77]$} \\
\hline
\end{tabular}

RT-PCR = valós idejű polimeráz-láncreakció

sekben fokozott lepényi expressziót írtak le. A miRNSek funkcionális hatásaira a tanulmányban nem tértek ki. Kimutatták, hogy a placentaspecifikus miRNS-ek elsősorban az anyai keringésben jelennek meg, ám az anyai eredetü miRNS-ek mind a placenta irányába, mind a magzati oldalra vándorolhatnak. Ezek alapján valószínüsíthető, hogy a terhességgel összefüggésben lévő miRNS-ek az anyai-magzati felszínek közötti kommunikáció egy eddig ismeretlen, nem hormonális módját határozzák meg.

Hromadnikova munkacsoportja jelentős munkát végzett a placentaspecifikus miRNS-ek tanulmányozásában. Eredményeik szerint a C19MC bizonyos tagjai biomarkerként szolgálhatnak nem csak a praeeclampsia, hanem az IUGR és a gesztációs hypertonia kórképek elöjelzésére is $[36,68,80]$. A vizsgált miRNS-ek szintje jelentősen megemelkedik a terhesség korai szakaszában, ami lehetőséget adhat az élettani és kóros kimenetelü terhességek elkülönítésére. Már fennálló betegség esetén csak a praeeclampsiás csoportban figyeltek meg szignifikáns különbséget [72].

Saját kutatásunk részeként meghatároztuk a miR-517es miRNS-család tagjainak expressziós mintázatát pla- centa- és anyai exoszómamintákban. Az eredményeket összehasonlítottuk praeeclampsiás és élettani terhességben, illetve az egyazon egyéntől származó placenta- és exoszómaminták között. A placentában mért hsa-miR$517 a / b$, a $h s a-m i R-517 c$ és a $h s a-m i R-517-5 p$ szintje a betegcsoportban 2-3-szor magasabb volt, mint a kontrollcsoportban. Meglepő módon az exoszómaminták között még hangsúlyosabb eltérés mutatkozott, mivel mindhárom miRNS expressziója 4-6-szor nagyobb volt a betegcsoportban. A párhuzamos placenta- és exoszómamintákban meghatározott miRNS-szintek nem vagy csak gyengén korreláltak egymással, ami alapján feltételezhető, hogy szekréciójuk aktív, irányított folyamatok révén valósul meg [81].

\section{A $h s a-m i R-210$ patogenetikai szerepe és expressziós mintázata praeeclampsiában}

A $h s a-m i R-210$ a leggyakrabban praeeclampsiával összefüggésbe hozott miRNS. Több kutatás is megerősítette, hogy a betegség fennállásakor mind a placentában, mind az anyai vérben megemelkedik a szintje [15]. Ez a miRNS egy úgynevezett „hypoxamiR”, neve a hypoxiás 
állapotra való érzékenységéból adódik [82]. A jól ismert HIFl $\alpha$ transzkripciós faktor közvetlenül a miRNS-promóter hypoxiareszponzív eleméhez (HRE) kötődik, aminek hatására a miRNS-transzkripció indukálódik (1. ábra) $[83,84]$. Ezt a jelenséget számos sejttípusban megfigyelték, beleértve a trophoblast- és az endothelsejteket is. Praeeclampsiában a placenta kóros fejlődése ischaemiás környezet kialakulásához vezet, ami hatással lehet a kibocsátott extracellularis vesiculák mennyiségére és tartalmára is.

Saját vizsgálatunkban a miRNS exoszomális mennyiségét vetettük össze különböző típusú terhességi magas vérnyomásos és kontrollcsoportok keringésében. Azt találtuk, hogy mind az össz-miRNS-koncentráció, mind a miR-210-szint emelkedett praeeclampsia esetén, s ez a kórkép súlyosságával tovább fokozódik [77]. Eredményeink alapján elmondható, hogy a hypoxiaszenzitív miRNS exoszómákba csomagolódik, aminek szerepe lehet a betegség patomechanizmusában.

Az intenzív kutatások ellenére még nem áll rendelkezésünkre bizonyíték arra vonatkozóan, hogy a miRNS hozzájárul-e a betegség kialakulásához, vagy inkább annak következménye. Eddig több mint hatvan gént validáltak kísérletesen a miR-210 célpontjaként, és ennél még több prediktált interakcióban vesz részt $[85,86]$. A szabályozott fehérjék fontos szerepet játszanak különböző sejtfolyamatokban, például apoptózisban, proliferációban és metabolizmusban.

A KCMFl protoonkogén fehérje, különböző epitheleredetû daganatokban serkenti a proliferációt, migrációt és inváziót [87]. Luo és mtsai HTR8/SVneo trophoblastsejtvonalon végzett vizsgálatukban kimutatták, hogy a miR-210 képes a KCMFl lecsendesítésére, ami csökkent trophoblastinvázióhoz vezet [47]. Placentában a $m i R-210$ upregulációja mitokondriális diszfunkcióhoz és oxidatív stresszhez vezethet egy az energiatermelésben fontos szerepet játszó fehérje gátlása révén [88]. Lee és mtsai igazolták, hogy az ISCU-fehérje a miR-210 szabályozása alatt áll SWAN71-trophoblast- és BeWo-choriocarcinoma-sejtvonalakban, továbbá a miRNS-mRNS párnak a placentában mért expressziója fordítottan arányos praeeclampsiás csoportban [89]. A miR-210 és miR-518c (a C19MC tagja) célpontja a HSD17Bl-gén által kódolt enzim, mely túlnyomórészt a placentában fejeződik ki, és szteroidhormonok bioszintézisében vesz részt. A fehérje szintjének csökkenése már a praeeclampsia klinikai tüneteinek megjelenése előtt kimutatható, ezért potenciális prognosztikai markerként szolgálhat [40]. Az EFNA3-és a HOXA9-gén is a miR210 célpontját képezi, s szintén fontos szerepet töltenek be a vascularisatio és a sejtek migrációja szempontjából, különösen a szív- és érrendszerben [44]. Kopriva és $m$ tsai a terhességi kórkép immunológiai vonatkozásaira irányuló kutatásokat végeztek. Igazolták, hogy a TLR3receptor aktivációja praeeclampsiára jellemző tünetek (endotheldiszfunkció, hypertonia és proteinurea) megjelenését idézi elő terhes egerekben. SGHPL4 típusú hu- mán cytotrophoblast (CTB)-sejtvonalon azt is bizonyították, hogy a TLR3-aktiváció miR-210-expressziót indukál, ami a STAT6/IL4 útvonal gátlása révén gyulladásos állapot kialakulásához vezet [58]. Anton és mtsai primer EVT sejtkultúrájában vizsgálták a $m i R-210$-overexpresszió hatását. Azt találták, hogy önmagában a miRNS hatását modellező „mimic” transzfekciója is elegendő volt a trophoblastinvázió gátlásához, ami szintén a patogén szerepet támasztja alá. Feltételezéseik szerint a miR-210 hatását az ERK/MAPK jelátviteli útvonal mediálja. A miRNS biomarker-szerepének meghatározására második trimeszteri szérummintákon prospektív kohorszvizsgálatot végeztek, és azt találták, hogy a miR-210 szintje már hónapokkal a betegség megjelenése előtt megemelkedik [69].

\section{Terápiás lehetőségek}

A trophoblasteredetû extracellularis vesiculák szerepének megértése élettani és kóros terhességben hozzájárulhat az új terápiás szerek fejlesztéséhez, melyek elősegíthetik a káros elemek semlegesítését, illetve a jótékony hatású faktorok felszabadítását. Nadkarni és mtsai kimutatták, hogy a rekombináns humánplazma-gelzolin korlátozza a spontán vesicula és a bennük lévő toxikus anyagok felszabadulását, beleértve az antiangiogén és proinflammatorikus tényezőket [90]. Salomon és mtsai placentaeredetű exoszómák bioaktivitását tanulmányozták humán köldökvénaendothelsejt-tenyészeten (HUVEC). Azt állapították meg, hogy az ilyen típusú vesiculákkal való inkubáció fokozza az endothelsejtek migrációját. Érdekes módon az exoszómák bioaktivitása az első trimeszterben volt a legnagyobb, és a terhesség előrehaladtával csökkent [14]. Ezek alapján feltételezhető, hogy a terhesség korai szakaszában a trophoblasteredetű exoszómák elősegítik az anyai érrendszer adaptációját.

A miRNS-ek heterogenitásának hátterében álló folyamatok feltárása szintén fontos feladat, mivel ezzel lehetővé válik a betegséget kialakító molekuláris interakciók pontosabb megismerése. A miRNS-szabályozási hálózatok feltérképezéséhez rendszerbiológiai szemlélet szükséges, mely magában foglalja nagy áteresztőképességű omikai technikák (genomika, transzkriptomika, proteomika stb.) és a nagy mennyiségű adatok feldolgozásához elengedhetetlen bioinformatikai eszközök alkalmazását.

\section{Következtetés}

A jövőben teret nyerhetnek a miRNS-terápiás lehetőségek: az úgynevezett miRNS- „mimic”-ek növelik az előnyös tulajdonságú miRNS-ek szintjét, míg az „antagomiR"-ek csökkentik a káros miRNS-ek expresszióját. Az előbbire példaként szolgál a már említett C19MC miRNS-ek antivirális védekezésben való alkalmazása, mely szabadalmi oltalom alatt áll (US9593334 B2). Ahhoz, hogy ezek az eszközök különböző terhességi kórképekben is alkalmazhatók legyenek, a klinikai vizs- 
gálatoknak kiemelt hangsúlyt kell fektetniük a lehetséges úgynevezett „off target” hatások minimalizálására, az időzítés és az adagolás pontos beállítására. A komoly mellékhatásokat elkerülendő, rendkívül fontos a szervezetbe jutó miRNS-ek célba juttatásának optimalizálása és az egyéb szövetekben esetlegesen kiváltott károsodások kiküszöbölése.

Anyagi támogatás: A közlemény megírása a Kll 13023 sz. OTKA-támogatásban részesült.

Szerzői munkamegosztás: A szerzók a kézirat elkészítésében egyenlő arányban vettek részt. A cikk végleges változatát mindkét szerző elolvasta és jóváhagyta.

Érdekeltség: A szerző́knek nincsenek érdekeltségeik.

\section{Irodalom}

[1] Duley L. The global impact of pre-eclampsia and eclampsia. Semin Perinatol. 2009; 33: 130-137.

[2] Tranquilli AL, Dekker G, Magee L, et al. The classification, diagnosis and management of the hypertensive disorders of pregnancy: A revised statement from the ISSHP. Pregnancy Hypertens. 2014; 4: 97-104.

[3] Alasztics B, Kukor Z, Pánczél Z, et al. The pathophysiology of preeclampsia in view of the two-stage model. [A praeeclampsia kórélettana a kétlépcsős modell tükrében.] Orv Hetil. 2012; 153: 1167-1176. [Hungarian]

[4] American College of Obstetricians and Gynecologists, Task Force on Hypertension in Pregnancy. Hypertension in pregnancy. Obstet Gynecol. 2013; 122: 1122-1131.

[5] Redman CW. Early and late onset preeclampsia: Two sides of the same coin. Pregnancy Hypertens. 2017; 7: 58.

[6] Raymond D, Peterson E. A critical review of early-onset and lateonset preeclampsia. Obstet Gynecol Surv. 2011; 66: 497-506.

[7] Craici I, Wagner S, Garovic VD. Review: Preeclampsia and future cardiovascular risk: formal risk factor or failed stress test? Ther Adv Cardiovasc Dis. 2008; 2: 249-259.

[8] Alasztics B, Gullai N, Molvarec A, et al. The role of angiogenic factors in preeclampsia. [Az angiogén faktorok szerepe praeeclampsiában.] Orv Hetil. 2014; 155: 1860-1866. [Hungarian]

[9] Escudero CA, Herlitz K, Troncoso F, et al. Role of extracellular vesicles and microRNAs on dysfunctional angiogenesis during preeclamptic pregnancies. Front Physiol. 2016; 7: 98.

[10] Raposo G, Stoorvogel W. Extracellular vesicles: Exosomes, microvesicles, and friends. J Cell Biol. 2013; 200: 373-383.

[11] Colombo M, Raposo G, Théry C. Biogenesis, secretion, and intercellular interactions of exosomes and other extracellular vesicles. Annu Rev Cell Dev Biol. 2014; 30: 255-289.

[12] Turchinovich A, Samatov TR, Tonevitsky AG, et al. Circulating miRNAs: Cell-cell communication function? Front Genet. 2013; 4: 119 .

[13] Kowal J, Arras G, Colombo M, et al. Proteomic comparison defines novel markers to characterize heterogeneous populations of extracellular vesicle subtypes. Proc Natl Acad Sci USA 2016; 113: E968-E977.

[14] Salomon C, Torres MJ, Kobayashi M, et al. A gestational profile of placental exosomes in maternal plasma and their effects on endothelial cell migration. PLoS ONE 2014; 9: e98667.

[15] Sheikh AM, Small HY, Currie G, et al. Systematic review of micro-RNA expression in pre-eclampsia identifies a number of common pathways associated with the disease. PLoS ONE 2016; 11: e0160808.
[16] Bounds KR, Chiasson VL, Pan LJ, et al. MicroRNAs: New players in the pathobiology of preeclampsia. Front Cardiovasc Med. 2017; 4: 60 .

[17] Salomon C, Guanzon D, Scholz-Romero K, et al. Placental exosomes as early biomarker of preeclampsia: Potential role of exosomal microRNAs across gestation. J Clin Endocrinol Metab. 2017; 102: 3182-3194.

[18] Murphy MS, Tayade C, Smith GN. Maternal circulating microRNAs and pre-eclampsia: Challenges for diagnostic potential. Mol Diagn Ther. 2017; 21: 23-30.

[19] Nothnick WB. MicroRNAs and endometriosis: Distinguishing drivers from passengers in disease pathogenesis. Semin Reprod Med. 2017; 35: 173-180.

[20] Poirier C, Desgagné V, Guérin R, et al. MicroRNAs in pregnancy and gestational diabetes mellitus: Emerging role in maternal metabolic regulation. Curr Diab Rep. 2017; 17: 35.

[21] Butz H, Patócs A. Technical aspects related to the analysis of circulating microRNAs. In: Igaz P. (ed.) Circulating microRNAs in disease diagnostics and their potential biological relevance. Experientia Supplementum 106. Springer, Basel, 2015; pp. 5571.

[22] miRBase. Homo sapiens miRNAs (1881 sequences). Available from: http://www.mirbase.org/cgi-bin/mirna_summary. pl?org=hsa [accessed: September 26, 2017].

[23] Yates LA, Norbury CJ, Gilbert RJ, et al. The long and short of microRNA. Cell 2013; 153: 516-519.

[24] Filipowicz W, Bhattacharyya SN, Sonenberg N. Mechanisms of post-transcriptional regulation by microRNAs: are the answers in sight? Nat Rev Genet. 2008; 2008: 102-114.

[25] Nagy Z, Igaz P. Introduction to microRNAs: Biogenesis, action, relevance of tissue microRNAs in disease pathogenesis, diagnosis and therapy - The concept of circulating microRNAs. In: Igaz P. (ed.) Circulating microRNAs in disease diagnostics and their potential biological relevance. Experientia Supplementum 106. Springer, Basel, 2015; 106: 3-30.

[26] Mouillet JF, Ouyang Y, Coyne CB, et al. MicroRNAs in placental health and disease. Am J Obstet Gynecol. 2015; 213: S163S172.

[27] Fu G, Brkić J, Hayder H, et al. MicroRNAs in human placental development and pregnancy complications. Int J Mol Sci. 2013; 14: 5519-5544.

[28] Mouillet JF, Chu T, Sadovsky Y. Expression patterns of placental microRNAs. Birth Defects Res Part A Clin Mol Teratol. 2011; 91: 737-743.

[29] Lykke-Andersen K, Gilchrist MJ, Grabarek JB, et al. Maternal argonaute 2 is essential for early mouse development at the maternal-zygotic transition. Mol Biol Cell 2008; 19: 4383-4392.

[30] Cheloufi S, Dos Santos CO, Chong MM, et al. A dicer-independent miRNA biogenesis pathway that requires Ago catalysis. Nature 2010; 465: 584-589.

[31] Morales-Prieto DM, Ospina-Prieto S, Schmidt A, et al. Elsevier trophoblast research award lecture: Origin, evolution and future of placenta miRNAs. Placenta 2014; 35: S39-S45.

[32] Morales-Prieto DM, Chaiwangyen W, Ospina-Prieto S, et al. MicroRNA expression profiles of trophoblastic cells. Placenta 2012; 33: 725-734.

[33] Seitz H, Royo H, Bortolin ML, et al. A large imprinted microRNA gene cluster at the mouse Dlkl-Gtl2 domain. Genome Res. 2004; 14: 1741-1748.

[34] Bortolin-Cavaille ML, Noguer-Dance $M$, Weber $M$, et al. C19MC microRNAs are processed from introns of large Pol-II, non-protein-coding transcripts. Nucleic Acids Res. 2009; 37: 3464-3473.

[35] Noguer-Dance M, Abu-Amero S, Al-Khtib M, et al. The primate-specific microRNA gene cluster (C19MC) is imprinted in the placenta. Hum Mol Genet. 2010; 19: 3566-3582.

[36] Hromadnikova I, Kotlabova K, Doucha J, et al. Absolute and relative quantification of placenta-specific microRNAs in mater- 
nal circulation with placental insufficiency-related complications. J Mol Diagnostics 2012; 14: 160-167.

[37] Dumont TM, Mouillet JF, Bayer A, et al. The expression level of C19MC miRNAs in early pregnancy and in response to viral infection. Placenta 2017; 53: 23-29.

[38] Schönleben M, Morales-Prieto DM, Markert U, et al. Association of the miR-371-3 cluster and trophoblast migration. J Reprod Immunol. 2016; 115: 57.

[39] Wang W, Feng L, Zhang H, et al. Preeclampsia up-regulates angiogenesis-associated microRNA (i.e., miR-17, -20a, and -20b) that target ephrin-B2 and EPHB4 in human placenta. J Clin Endocrinol Metab. 2012; 97: E1051-E1059.

[40] Chen S, Zhao G, Miao H, et al. MicroRNA-494 inhibits the growth and angiogenesis-regulating potential of mesenchymal stem cells. FEBS Lett. 2015; 589: 710-717.

[41] Zhang Y, Diao Z, Su L, et al. MicroRNA-155 contributes to preeclampsia by down-regulating CYR61. Am J Obstet Gynecol. 2010; 202: 466.el-466.e7.

[42] Liu LZ, Li C, Chen Q, et al. MiR-21 induced angiogenesis through AKT and ERK activation and HIF- $1 \alpha$ expression. PLoS ONE 2011; 6: el9139.

[43] Ishibashi O, Ohkuchi A, Ali MM, et al. Hydroxysteroid (17- $\beta$ ) dehydrogenase 1 is dysregulated by miR-210 and miR- $518 \mathrm{c}$ that are aberrantly expressed in preeclamptic placentas: A novel marker for predicting preeclampsia. Hypertension 2012; 59: 265273.

[44] Zhang Y, Fei M, Xue G, et al. Elevated levels of hypoxia-inducible microRNA-210 in pre-eclampsia: new insights into molecular mechanisms for the disease. J Cell Mol Med. 2012; 16: 249259.

[45] Li Q, Pan Z, Wang X, et al. miR-125b-1-3p inhibits trophoblast cell invasion by targeting sphingosine-1-phosphate receptor 1 in preeclampsia. Biochem Biophys Res Commun. 2014; 453: 5763.

[46] Doridot L, Houry D, Gaillard H, et al. miR-34a expression, epigenetic regulation, and function in human placental diseases. Epigenetics 2014; 9: 142-151.

[47] Luo R, Shao X, Xu P, et al. MicroRNA-210 contributes to preeclampsia by downregulating potassium channel modulatory factor 1. Hypertension 2014; 64: 839-845.

[48] Li X, Li C, Dong X, et al. MicroRNA-155 inhibits migration of trophoblast cells and contributes to the pathogenesis of severe preeclampsia by regulating endothelial nitric oxide synthase. Mol Med Rep. 2014; 10: 550-554.

[49] Dai Y, Diao Z, Sun H, et al. MicroRNA-155 is involved in the remodelling of human-trophoblast-derived HTR-8/SVneo cells induced by lipopolysaccharides. Hum Reprod. 2011; 26: 1882 1891.

[50] Luo L, Ye G, Nadeem L, et al. MicroRNA-378a-5p promotes trophoblast cell survival, migration and invasion by targeting Nodal. J Cell Sci. 2012; 125: 3124-3132.

[51] Chaiwangyen W, Ospina-Prieto S, Photini SM, et al. Dissimilar microRNA-21 functions and targets in trophoblastic cell lines of different origin. Int J Biochem Cell Biol. 2015; 68: 187-196.

[52] Fu G, Ye G, Nadeem L, et al. MicroRNA-376c impairs transforming growth factor- $\beta$ and Nodal signaling to promote trophoblast cell proliferation and invasion. Hypertension 2013; 61: 864-872.

[53] Kumar P, Luo Y, Tudela C, et al. The c-Myc-regulated microRNA-17 92 (miR-17 92) and miR-106a 363 clusters target hCYP19Al and hGCMl to inhibit human trophoblast differentiation. Mol Cell Biol. 2013; 33: 1782-1796.

[54] Xue P, Zheng M, Diao Z, et al. miR-155* mediates suppressive effect of PTEN 3 '-untranslated region on AP- $1 / \mathrm{NF}-\kappa \mathrm{B}$ pathway in HTR-8/SVneo cells. Placenta 2013; 34: 650-656.

[55] Zhao G, Miao H, Li X, et al. TGF- $\beta 3$-induced miR-494 inhibits macrophage polarization via suppressing PGE2 secretion in mesenchymal stem cells. FEBS Lett. 2016; 590: 1602-1613.
[56] Liu L, Wang Y, Fan H, et al. MicroRNA-181a regulates local immune balance by inhibiting proliferation and immunosuppressive properties of mesenchymal stem cells. Stem Cells 2012; 30: 1756-1770.

[57] Zhu X, Han T, Wang X, et al. Overexpression of miR-152 leads to reduced expression of human leukocyte antigen-G and increased natural killer cell mediated cytolysis in JEG-3 cells. Am J Obstet Gynecol. 2010; 202: 592.el-592.e7.

[58] Kopriva SE, Chiasson VL, Mitchell BM, et al. TLR3-induced placental miR-210 down-regulates the STAT6/interleukin-4 pathway. PLoS ONE 2013; 8: e67760.

[59] Yang W, Wang A, Zhao C, et al. miR-125b enhances IL-8 production in early-onset severe preeclampsia by targeting sphingosine-1-phosphate lyase 1. PLoS ONE 2016; 11: e0166940.

[60] Biró O, Nagy B, Rigó J. Identifying miRNA regulatory mechanisms in preeclampsia by systems biology approaches. Hypertens Pregnancy 2017; 36: 90-99.

[61] Xie L, Mouillet JF, Chu T, et al. C19MC microRNAs regulate the migration of human trophoblasts. Endocrinology 2014; 155: $4975-4985$.

[62] Anton L, Olarerin-George AO, Hogenesch JB, et al. Placental expression of miR-517a/b and miR-517c contributes to trophoblast dysfunction and preeclampsia. PLoS ONE 2015; 10: e0122707.

[63] Delorme-Axford E, Donker RB, Mouillet J-F, et al. Human placental trophoblasts confer viral resistance to recipient cells. Proc Natl Acad Sci USA 2013; 110: 12048-12053.

[64] Mouillet JF, Ouyang Y, Bayer A, et al. The role of trophoblastic microRNAs in placental viral infection. Int J Dev Biol. 2014; 58 : 281-289.

[65] Chen X, Ba Y, Ma L, et al. Characterization of microRNAs in serum: a novel class of biomarkers for diagnosis of cancer and other diseases. Cell Res. 2008; 18: 997-1006.

[66] Gilad S, Meiri E, Yogev Y, et al. Serum microRNAs are promising novel biomarkers. PLoS ONE 2008; 3: e3148.

[67] Ura B, Feriotto G, Monasta L, et al. Potential role of circulating microRNAs as early markers of preeclampsia. Taiwan J Obstet Gynecol. 2014; 53: 232-234.

[68] Hromadnikova I, Kotlabova K, Ivankova K, et al. First trimester screening of circulating C19MC microRNAs and the evaluation of their potential to predict the onset of preeclampsia and IUGR. PLOS ONE 2017; 12: e0171756.

[69] Anton L, Olarerin-George AO, Schwartz N, et al. miR-210 inhibits trophoblast invasion and is a serum biomarker for preeclampsia. Am J Pathol. 2013; 183: 1437-1445.

[70] Xu P, Zhao Y, Liu M, et al. Variations of microRNAs in human placentas and plasma from preeclamptic pregnancy. Hypertension 2014; 63: 1276-1284.

[71] Yang Q, Lu J, Wang S, et al. Application of next-generation sequencing technology to profile the circulating microRNAs in the serum of preeclampsia versus normal pregnant women. Clin Chim Acta 2011; 412: 2167-2173.

[72] Hromadnikova I, Kotlabova K, Ondrackova M, et al. Circulating C19MC microRNAs in preeclampsia, gestational hypertension, and fetal growth restriction. Mediators Inflamm. 2013; 2013: 186041.

[73] Gunel T, Zeybek YG, Akçakaya P, et al. Serum microRNA expression in pregnancies with preeclampsia. Genet Mol Res. 2011; 10: 4034-4040.

[74] Wu L, Zhou H, Lin H, et al. Circulating microRNAs are elevated in plasma from severe preeclamptic pregnancies. Reproduction 2012; 143: 389-397.

[75] Zhu S, Cao L, Zhu J, et al. Identification of maternal serum microRNAs as novel non-invasive biomarkers for prenatal detection of fetal congenital heart defects. Clin Chim Acta 2013; 424: 66-72.

[76] Murphy MS, Casselman RC, Tayade C, et al. Differential expression of plasma microRNA in preeclamptic patients at delivery 
and 1 year postpartum. Am J Obstet Gynecol. 2015; 213: 367. el-367.e9.

[77] Biró O, Alasztics B, Molvarec A, et al. Various levels of circulating exosomal total-miRNA and miR-210 hypoxamiR in different forms of pregnancy hypertension. Pregnancy Hypertens. 2017; 10: 207-212.

[78] Miura K, Higashijima A, Murakami Y, et al. Circulating levels of pregnancy-associated, placenta-specific microRNAs in pregnant women with placental abruption. Reprod Sci. 2017; 24: 148155 .

[79] Chang G, Mouillet J-F, Mishima T, et al. Expression and trafficking of placental microRNAs at the feto-maternal interface. FASEB J. 2017; 31: 2760-2770.

[80] Hromadnikova I, Kotlabova K, Hympanova L, et al. First trimester screening of circulating C19MC microRNAs can predict subsequent onset of gestational hypertension. PLoS ONE 2014; 9 : el13735.

[81] Biró O, Fóthi Á, Alasztics B, et al. The expression profile of miR517 family members in preeclamptic placenta and circulating exosome samples. Pregnancy Hypertens. 2017; 9: 46.

[82] Chan SY, Loscalzo J. MicroRNA-210: a unique and pleiotropic hypoxamir. Cell Cycle 2010; 9: 1072-1083.

[83] Huang X, Le QT, Giaccia AJ. MiR-210-micromanager of the hypoxia pathway. Trends Mol Med. 2010; 16: 230-237.

[84] Huang X, Ding L, Bennewith KL, et al. Hypoxia-inducible mir210 regulates normoxic gene expression involved in tumor initiation. Mol Cell 2009; 35: 856-867.
[85] miRWalk2.0: a comprehensive atlas of predicted and validated miRNA-target interactions. Available from: http://zmf.umm. uni-heidelberg.de/apps/zmf/mirwalk2/ [accessed: September 26, 2017].

[86] miRTarBase: the experimentally validated microRNA-target in teractions database. Available from: http://mirtarbase.mbc. nctu.edu.tw/ [accessed: September 26, 2017].

[87] Beilke S, Oswald F, Genze F, et al. The zinc-finger protein KCMFl is overexpressed during pancreatic cancer development and downregulation of KCMFl inhibits pancreatic cancer development in mice. Oncogene 2010; 29: 4058-4067.

[88] Muralimanoharan S, Maloyan A, Mele J, et al. MIR-210 modulates mitochondrial respiration in placenta with preeclampsia. Placenta 2012; 33: 816-823.

[89] Lee DC, Romero R, Kim JS, et al. miR-210 targets iron-sulfur cluster scaffold homologue in human trophoblast cell lines. Am J Pathol. 2011; 179: 590-602.

[90] Nadkarni NA, Rajakumar A, Mokhashi N, et al. Gelsolin is an endogenous inhibitor of syncytiotrophoblast extracellular vesicle shedding in pregnancy. Pregnancy Hypertens. 2016; 6: 333339.

(Biró Orsolya, Budapest, Baross u. 27., 1088 e-mail cím: biro.orsolya@noil.sote.hu)

\title{
MEGHÍVó
}

\section{Markusovszky Lajos-emlékülés}

2018. május 3. (csütörtök) 11 óra

\author{
Aesculap Akadémia konferenciaterme \\ (Budapest XI., Halmi u. 20-22.-Tétényi út 12-16. sarok)
}

A Markusovszky Lajos Alapítvány Kuratóriuma és az Akadémiai Kiadó meghívja Önt az Orvosi Hetilap Szerkesztőbizottságának és Szerkesztőségének hagyományos évi Markusovszky Lajos-emlékülésére, melyet az Orvosi Hetilap alapítója halálának 125. évfordulója tiszteletére rendezünk.

\section{PROGRAM}

\section{Főszerkesztői köszöntés és beszámoló}

Prof. Dr. Papp Zoltán

\author{
A Markusovszky Lajos Alapítvány és a Dr. Fehér János Emlékére Alapítvány 2018. évi kitüntetéseinek ünnepélyes \\ átadása \\ - „Orvosi Hetilap Markusovszky Lajos-emlékérem” \\ - „Orvosi Hetilap Markusovszky Lajos-dí”” \\ - A referensek munkájának elismerése \\ - „Dr. Fehér János Emlékére Alapítvány-dí”
}

\section{Markusovszky Lajos-emlékelőadás}

Kiss László dr.: A himlő elleni védőoltás magyarországi története

\section{Az Orvosi Hetilap értékelése}

Dr. Réffy Balázs, az Akadémiai Kiadó vezérigazgatója

Fogadás

$$
\text { Az ünnepségre szeretettel várjuk! }
$$

Kérjük, jelezze részvételi szándékát Budai Editnél az edit.budai@akademiai.hu e-mail címen. 